\title{
Audacity Software Analysis in Analyzing the Frequency and Character of the Sound Spectrum
}

\author{
Aisha Azalia ${ }^{1 *}$, Desi Ramadhanti ${ }^{1}$, Hestiana $^{1}$, Heru Kuswanto ${ }^{1}$ \\ ${ }^{1}$ Department of Science Education, Faculty of Science and Mathematics, Universitas Negeri Yogyakarta, Daerah Istimewa Yogyakarta, \\ Indonesia.
}

\section{DOI: $10.29303 /$ jppipa.v8i1.913}

\section{Article Info}

Received: August 24, 2021

Revised: January 8, 2022

Accepted: January 11, 2022

Published: January 31, 2022

\begin{abstract}
In the process of learning physics, experiments are needed that can help someone in gaining a deeper understanding of learning physics concepts and using technology in the learning process, especially learning sound waves. In this study, the aim is to be able to analyze the sound frequency with the help of the Audacity software. Subjects used are 5 different cat sounds. The implementation of this research uses several tools such as a microphone, audacity software on a laptop and 5 cat sounds. This experiment was carried out by bringing the micro hope closer to the cat with $5 \mathrm{~cm}$ so that the sound was captured by the microphone which would later be transferred to the laptop and read by the audacity software. Furthermore, the data recorded in audacity were analyzed. From the results of the study, it can be said that a tool that can be used in practicum and can read and capture sound waves is effectively used in analyzing sound frequency, spectrum in the application of sound learning so that it can be used as one of the learning media in practicum on sound wave material at Junior high school.
\end{abstract}

Keywords: Sound waves; Audacity Software; Spectrum; Frequency; Science

Citation: Azalia, A., Ramadhanti, D., Hestiana, H., \& Kuswanto, H. (2022). Audacity Software Analysis In Analyzing The Frequency And Character Of The Sound Spectrum. Jurnal Penelitian Pendidikan IPA, 8(1), 177-182. https://doi.org/10.29303/jppipa.v8i1.913

\section{Introduction}

Halliday (2002) states that waves are vibrational energy vines that can propagate through the medium or without going through the medium. The tethered medium can be liquid, gaseous or solid. Based on its propagations, waves are divided into two types, namely longitudinal and transverse waves. Transverse waves are waves that have perpendicular propagations with vibration and medium while longitudinal waves are the opposite where the waves that have vines are parallel to the vibration and medium (Bambang, 2008). One example of the application of waves is the presence of sound waves. Sound is a mechanical wave with a type of longitudinal that propagates and there is a source of sound in the form of vibrating objects (Giancoli, 2001).
One of the interesting topics to be able to do experiments in the learning process is sound. Sound waves are waves due to the presence of suction and stretching on the gas medium. An example of its application with the resulting sound when the tuning fork is shaken will cause density disturbances in the medium so that it will cause the rapid appearance of sound rambat on the gas medium (Tipler, 1991). Each sound source will have a different characteric sound. These characteristic differences are seen based on the frequency and intensity values of the sound source. One of the learning materials in school is sound wave material that requires one of the experiments where students can know the characteristics of sound, especially frequency, amplitude, period, and wave.

Research on the analysis of sound waves, especially the frequency of sound by designing a tool to determine the speed of sound rambat in the air using 
an impedance tube with a sound source namely Audio Frequency Generator (AFG) with a frequency From 300 - 1000 Hz. Novikarany (2010) research how to measure the speed of sound waves in the air based on microcontrollers obtained that automatically by conducting performance tests where all data obtained is processed using a microcontroller and the results are displayed in the form of LCD with sound wave values in the air in the medium of organa pipes with varying frequency values. Experimental tools in determining sound usually use open or closed organa pipes where the tool is less effective if carried everywhere and takes a long time to analyze it, especially in the learning process in schools (Astuti, 2016).

Practicum devices in schools, especially in the learning process, are needed as a learning medium that plays an important role in the success of the learning process in schools, especially independent learning that is now driven by education. The existence of this experiment will make students better able to understand the concept of physics learning given especially in this sound wave material with an experiment or simple experiment by utilizing existing media. Wave and sound materials are materials that are very difficult for students to understand. Therefore, the need for interactive learning media so that students will easily understand the material (Yanto, et al., 2015). The existence of learning media in open organa pipe material by combining cultural elements, the art of utilization of existing technological developments is expected that students will be more interested in learning. Therefore, it takes a simpler tool, easy to assemble, and run by students. To be able to carry out an experiment that is suitable for sound recording equipment such as microphone or hydrophones where the use of the recording device is called passive sounding (Pranoto, 2018) The process of sound recording or processing of sound signals, in addition to the recording device is also needed equipment in the form of software. One type of software that can be used is audacity.

In this study will use a simple experimental tool and analyzed quickly and precisely where audacity is a free licensed sound file processing software. One of the functions of audacity is the ability to record sound signals that are inside the computer, as well as from outside the computer (Farida, et al., 2020). Research conducted by Nursulistiyo (2015) where he used pentatonic bamboo flutes as a medium of physics learning and categorized both as a medium of physics learning in open organa pipe material. Widayanti and Pramudya's (2014) research also looked at the frequency of bonang barung where data obtained by recording sound with audacity software and analyzed with the analysis facilities in the program, so that the frequency of sound obtained. So, in this study, researchers formulated ideas or ideas to be able to analyze the use of audacity software for the implementation of sound wave experiments in life. The data obtained from this experiment is expected to be used as a reference material in science and can know the frequency testing spectrum with the help of existing software that is audiocity software. This article can be used in generating a practicum by using applications in everyday life.

\section{Method}

This type of research is a type of research used is descriptive research that aims to provide an overview of a symptom, event, and actual state in this case will describe clearly about the frequency and character of the spectrum. This research place is Karangmalang block a no 51, sleman, Yogyakarta. The research object is 5 cats so that the object is easy to find. The implementation of this physics experiment tool is a test in seeing sound waves, especially frequency-assisted audacity software. The tools and materials used in this experiment are laptops with audacity program and 5 sounds that have been described. The experimental procedure as can be seen in Figure 1.

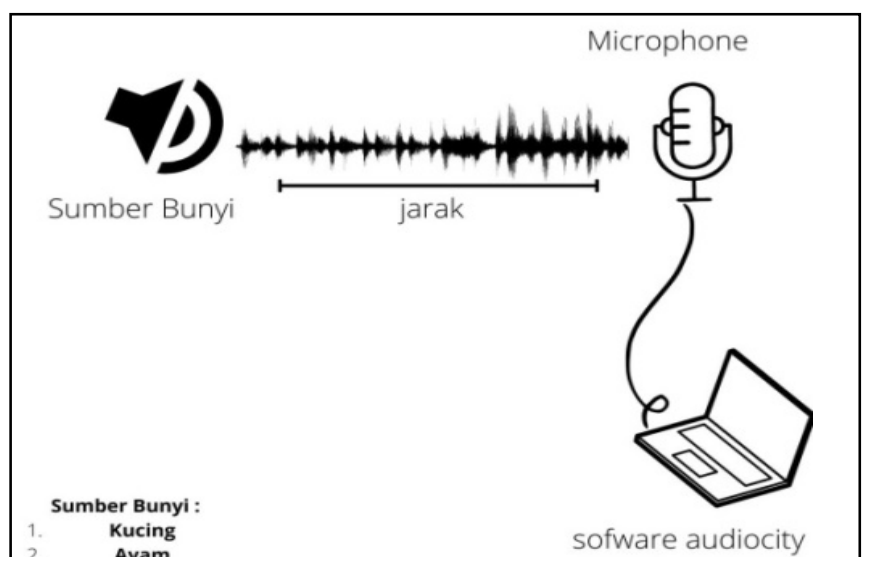

Figure 1. Implementation Process

- Turn on the laptop and activate the audacity program.

- Connect the microphone with the adapter and laptop as shown in figure 1.

- Set the distance between the microphone and the cat at a distance of $5 \mathrm{~cm}$.

- Captures cat sounds $5 x$

- Analyze the data obtained by placing the most sounding sounds in audacity

\section{Result and Discussion}

Based on the results of experiments conducted obtained data spectrum shape and frequency of sound sounds in cats. In this study was conducted on 5 cat sounds under different conditions. The explanation of 
the condition of the cat analyzed can be seen from Table 1 .

Table 1. Cat Description Analyzed

\begin{tabular}{llll}
\hline Name & Gender & Type Cat & Condition \\
\hline Cat 1 & Female & Domestik & 10-month-old cat \\
Cat 2 & Male & Domestik & 3 months old cat \\
Cat 3 & Male & Anggora & 1 year old cat \\
Cat 4 & Female & Mixed Anggora & 2 years old cat \\
Cat 5 & Female & Mixed Persia & 1 year old \\
\hline
\end{tabular}

In Table 1, researchers examined 5 cats analyzed under different conditions and different ages, the cat samples were taken and also analyzed with audaicity. In the audacity display will be visible signals or sound waves, as in Figure 2 to Figure 6. After being recorded in audacity then analyze and process the data for the existing frequency value, as seen in the picture that the frequency value of 5 cats that have been analyzed that does not reach at $20,000 \mathrm{~Hz}$ is only about $15,000-16,000$ $\mathrm{Hz}$ under any circumstances.

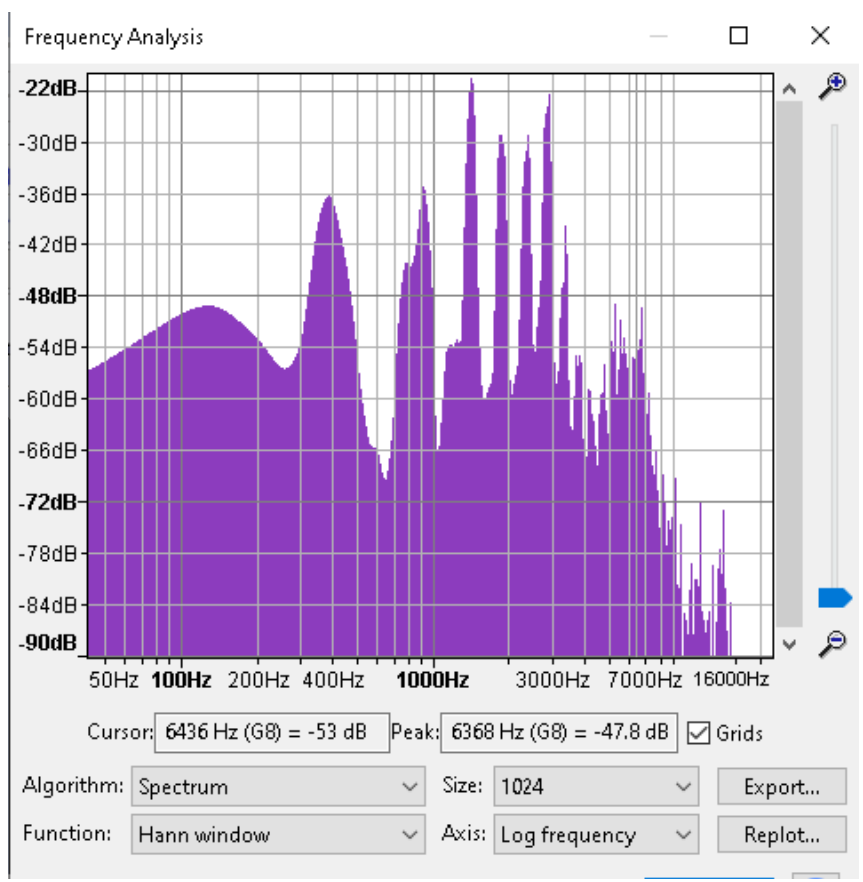

Figure 2. Cat Voice 1

Table 2. Analysis Frequency 1

\begin{tabular}{ll}
\hline Frekuensi $(\mathrm{Hz})$ & Amplitudo $(\mathrm{dB})$ \\
\hline 44 & 55 \\
84 & 60 \\
123 & 48 \\
382 & 36.20 \\
912 & 35.20 \\
2957 & 23.60 \\
6850 & 55.50 \\
11.270 & 81.50 \\
\hline
\end{tabular}

In figure 2, you can see that the sound graphs in female domestic cats have a changing frequency of sound. Based on the existing spectrum, describes that the initial frequency of sound is $50 \mathrm{~Hz}$ then increasing and reaching $16,000 \mathrm{~Hz}$. While for the amplitude of sound from $-22 \mathrm{~dB}$ to $-90 \mathrm{~dB}$. At the highest point of yiatu $11,217 \mathrm{~Hz}$ with an amplitude of $-81.5 \mathrm{~dB}$ while the lowest sound amplitude with $-47.8 \mathrm{~dB}$ at the sound frequency at the point of $6,368 \mathrm{~Hz}$. In table 2 it can be seen that the amplitude at each frequency is different. Sometimes high and sometimes low at $44 \mathrm{~Hz}$ amplitude obtained is $55 \mathrm{~dB}$ while after at a frequency of $2957 \mathrm{~Hz}$ amplitude $23.6 \mathrm{~dB}$. Although it has a high frequency does not mean it will have a high amplitude anyway.

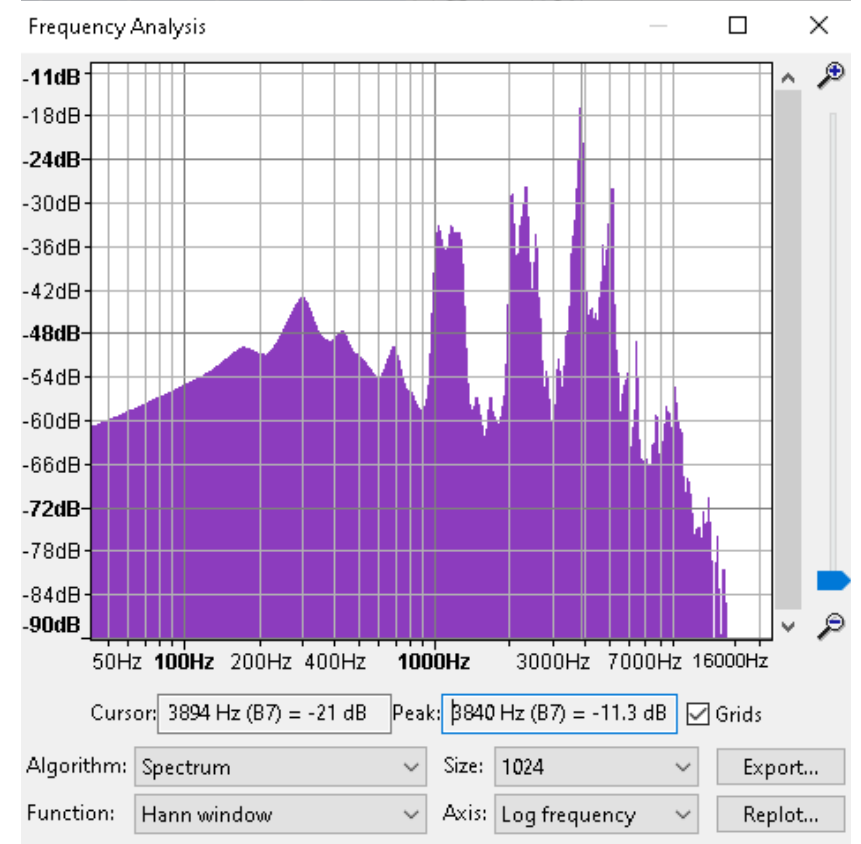

Figure 3. Cat Voice 2

Table 3. Analysis Frequency 2

\begin{tabular}{ll}
\hline Frekuensi $(\mathrm{Hz})$ & Amplitudo $(\mathrm{dB})$ \\
\hline 44 & 59 \\
91 & 55 \\
167 & 49.70 \\
417 & 42.20 \\
1037 & 32.20 \\
2315 & 27.30 \\
4131 & 35.10 \\
13502 & 74.60 \\
\hline
\end{tabular}

In figure 3, it can be seen that domestic cats of this male sex have a changing frequency of sound. Based on the spectrum, the highest point of sound amplitude with $-74.6 \mathrm{~dB}$ at $13,502 \mathrm{~Hz}$ while the lowest at $-11.3 \mathrm{~dB}$ obtained sound frequency at $3,840 \mathrm{~Hz}$ while on Table 3 can be seen that amplitude at each frequency varies. Sometimes high and sometimes low at $44 \mathrm{~Hz}$ amplitude obtained is $59 \mathrm{~dB}$ while after at a frequency of $2315 \mathrm{~Hz}$ amplitude $27.2 \mathrm{~dB}$. In figure 4 , it can be seen that the 
male anggora cat has a changing frequency of sound. Based on the spectrum, the highest point of sound amplitude is $-87.1 \mathrm{~dB}$ with a frequency of $10,964 \mathrm{~Hz}$ and the lowest with $-22.3 \mathrm{~dB}$ at $1,997 \mathrm{~Hz}$ while in table 4 the data obtained also changed and differed. Data obtained that the frequency does not settle or increase in each frequency where at a frequency of $43 \mathrm{~Hz}$ has amplitude - $53 \mathrm{~dB}$ while at the frequency point $1197 \mathrm{~Hz}$ has 22.3 dB.

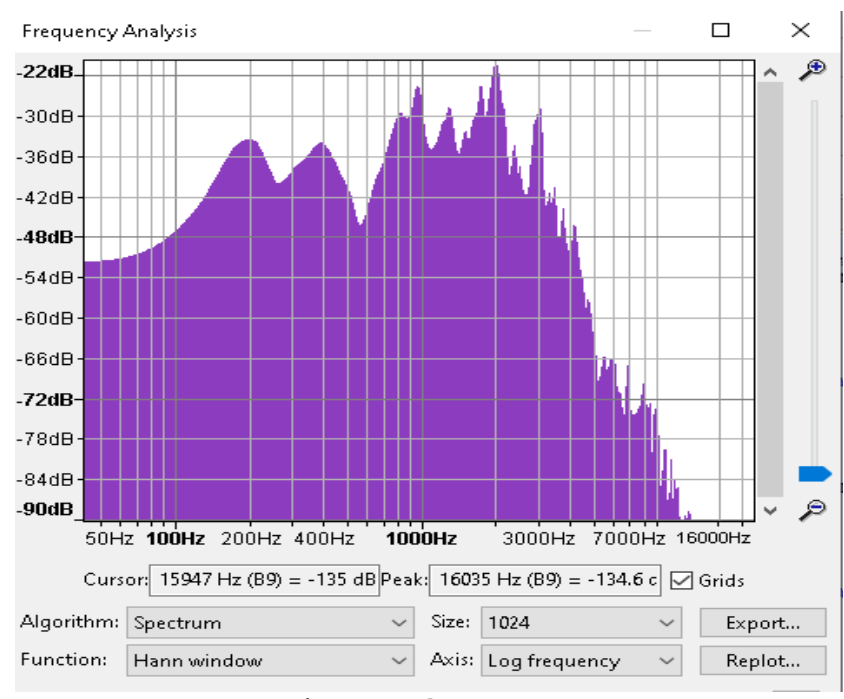

Figure 4. Cat Voice 3

Table 4. Analysis Frequency 3

\begin{tabular}{lc}
\hline Frekuensi $(\mathrm{Hz})$ & Amplitudo $(\mathrm{dB})$ \\
\hline 43 & 51 \\
135 & 32.60 \\
195 & 32.60 \\
384 & 33.90 \\
960 & 25.70 \\
1997 & 22.30 \\
2982 & 28.60 \\
6282 & 69.80 \\
10964 & 87.10 \\
\hline
\end{tabular}

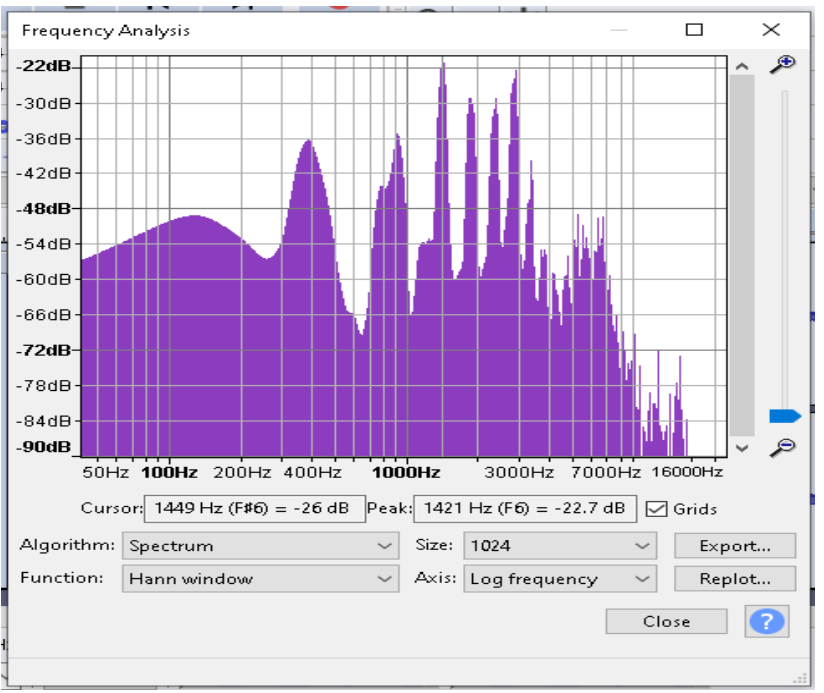

Figure 5. Cat Voice 4
Table 5. Analysis Frequency 4

\begin{tabular}{lc}
\hline Frekuensi $(\mathrm{Hz})$ & Amplitudo $(\mathrm{dB})$ \\
\hline 88 & 38.8 \\
157 & 35.5 \\
463 & 42.2 \\
1540 & 28.7 \\
3273 & 28.5 \\
5734 & 35.1 \\
14423 & 22.7 \\
\hline
\end{tabular}

In figure 5, it can be seen that the female mixed anggora cat has a changed frequency of sound - change with a different amplitude of sound. Based on existing spectrum, the highest point of sound amplitude is -81.9 $\mathrm{dB}$ at $14,423 \mathrm{~Hz}$ and the lowest is $-22.7 \mathrm{~dB}$ with a frequency of $1,824 \mathrm{~Hz}$. In table 5 it is also seen that the frequency data changes where at $88 \mathrm{~Hz}$ amplitude obtained is $-38.8 \mathrm{~dB}$ while at the frequency point 3273 $\mathrm{Hz}$ drops to $-28.5 \mathrm{~dB}$

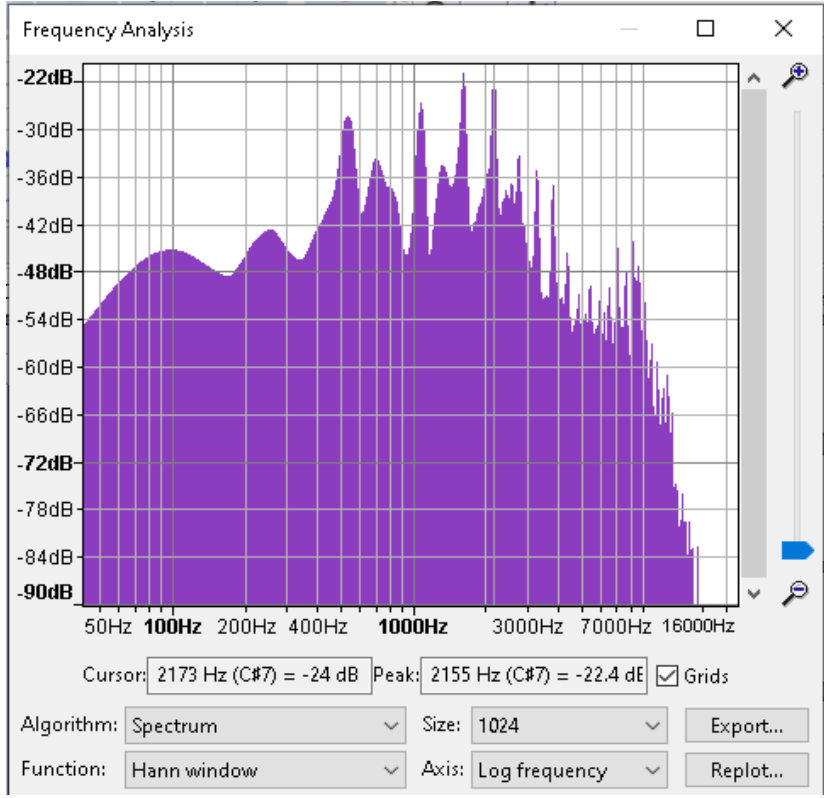

Figure 6. Cat Voice 5

Table 6. Analysis Frequency 5

\begin{tabular}{ll}
\hline Frekuensi $(\mathrm{Hz})$ & Amplitudo $(\mathrm{dB})$ \\
\hline 44 & 53 \\
99 & 45.20 \\
247 & 42.50 \\
535 & 28.30 \\
1073 & 26.60 \\
2707 & 32.30 \\
6434 & 49.10 \\
14540 & 103.90 \\
\hline
\end{tabular}

In figure 6, it can be seen that mixed Persian cats of female sex have a changing frequency of sound. Based on the spectrum, the lowest point of sound amplitude is $-22.4 \mathrm{~dB}$ with a frequency of $2,155 \mathrm{~Hz}$ while the highest is $-103.9 \mathrm{~dB}$ with a frequency of $14,540 \mathrm{~Hz}$. In table 6 obtained data that the frequency of the cat pad 
from the data obtained can be seen in Table 6 the same as in other analysis where the amplitude at each frequency is not fixed and does not increase but changed for the data that will show the highest and lowest points in the sound recorded can be seen in table 7.

Table 7. Data Analysis

\begin{tabular}{llll}
\hline No & Sound Point & Frekuensi $(\mathrm{Hz})$ & Amplitudo $(\mathrm{dB})$ \\
\hline 1 & Highest & 11.217 & 81.50 \\
& Lowest & 6.368 & 47.80 \\
2 & Highest & 13.502 & 74.60 \\
& Lowest & 3.840 & 11.30 \\
3 & Highest & 10.964 & 87.10 \\
& Lowest & 1.997 & 22.30 \\
4 & Highest & 14.473 & 81.90 \\
& Lowest & 1.824 & 28.90 \\
5 & Highest & 14.540 & 103.90 \\
& Lowest & 2.155 & 22.40 \\
\hline
\end{tabular}

Frequency measurement using audacity for various purposes is widely carried out. Measurement of sound frequency is the number of sound vibrations formed during one unit of time. The use of frequencies, tones and levels of sounds has also been widely developed in the fields of health, agriculture (Larry, 2015) and even weapons. From the frequency, amplitude and pitch of sound, many things can be distinguished, ranging from gender, animal sound characteristics, hearing limits of living things to social characteristics of society. Audacity can help design experimental tool designs and determine the value of the speed of sound propagation both the frequency and the sound amplitude (Astuti, 2016). The use of audacity software helps the process of analyzing frequencies well and easily so that it can get the desired and expected data. Based on the data obtained shows that the cat's voice has a frequency of both low and high pitch frequencies, but the intensity is not always the same due to the subjectivity of the sound emitted. For the highest frequency at 5 sounds analyzed at vulnerable $14,540 \mathrm{~Hz}$ with an intensity of -103.9 while for the lowest $1,997 \mathrm{~Hz}$ with $-22.3 \mathrm{~dB}$. So, from the data obtained that the amplitude does not affect the frequency and although the amplitude is long or short then the frequency and period will remain the same.

A voice is never silent but constantly changes over time. This means that each sinusoid amplitude changes so that the shape of the graph representing the spectrum also changes. This explains what we see when we pay attention to spectrum analysis with its glowing LEDs. The LED shows the amplitude of the sinusoid-sinusoid in the spectrum. This explains the behavior of the graphic equalizer: amplification or attenuation of sinusoid amplitudes. The interval of 20 $\mathrm{Hz}-20 \mathrm{kHz}$ is continuous, so in the equalizer, each cursor controls the amplitude of one frequency band.
The more cursors there are, the narrower the bandwidth is controlled. In the case of the theoretical ideal of infinite cursors, each would control the amplitude of a single sinusoid (Pandeya, 2018). The data also found that sex also affects the frequency of sounds in the voice of cats where the frequency of the voice of the male cat is smaller than that of the female cat while the intensity of the sound does not affect both the male and female cats.

This application can measure the frequency of this sound produced, by using software audacity will be able to measure the level of sound intensity produced by the sound source. The level of sound intensity produced at has a very significant difference. This is because the air in the environment is not constant, so it affects the magnitude of the intensity of the sound produced. By learning sound waves using sounds in life will be more interesting and can be done anywhere, be it at home or in school. With the existence of Audacity software, it can help teachers create learning media that are suitable for learning in schools, especially with the use of technology, so as to enable students to learn with high motivation because of their interest in multimedia systems that are able to present animation, sound, graphics and text displays (Leman, 2021). A combination of technology and physics can be used by teachers to invite students during the learning process. If the development of technology is used as a learning medium, it will have a good impact for everyone including the students themselves.

This experimental tool is validated by validators or experts in physics. The experiment tool can be used for practicum with revisions as per the validator's suggestion. The suggestion is that the tool sets are arranged in one place so that they look neat, and easy to carry around. Equipped with ordinances or instructions for the use of tools so that students can carry out experiments independently. In carrying out the experiment should be considered the condition or state of the room such as temperature and noise level. For the desired results to approach the theoretical value, it would be nice to have an experiment conducted in a soundproofed room in this age of rapid development of science and technology, it is supposed to develop a technology-based learning medium so that this audacity is worth using in helping the process of implementing one of the experiments on sound wave material.

\section{Conclusion}

Based on the result, Audacity software that can be used in practicum and can read and capture sound waves is effectively used in analyzing sound frequency, spectrum in the application of sound learning so that it can be used as one of the learning media in practicum 
on sound wave material specially for Junior high school.

\section{Acknowledgments}

The author would like to thank all those who have helped in this research, especially parents, lecturers of the study of physics in living systems

\section{References}

Astuti, I.A.D. (2016). Pengembangan Alat Eksperimen Cepat Rambat Bunyi Dalam Medium Udara Dengan Menggunakan Metode Time of Flight (Tof) Dan Berbantuan Software Audacity. Unnes Physics Education Journal. 5(3). https://doi.org/10.15294/upej.v5i3.13725

Bambang. (2008). Fisika Dasar. Yogyakarta: ANDI

Farida, N. Melati, P., Ruqoyah, R., Yuristyansyah, V., \& Antarnusa, G. (2020). Pengaruh Amplitudo (A), Frekuensi (f), Dan Tegangan Gelombang Pada Tali Berbasis PheT Simulation. Jurnal Untirta. 3(1), 408414. Retrieved from: https://jurnal.untirta.ac.id/index.php/sendikfi/a rticle/view/9721

Giancoli, D. C. (2001). Fisika (5 ed., Vol. 1). (H. H. Wibi, Penyunt., \& Y. Hanum, Penerj.) Jakarta: Erlangga.

Halliday, M.A.K. (2002). Text as Semantic Choice in Social Context. Dalam WeBMter, J. J. (ed.) Linguistic Studies of Textand Discourse: 23-81. London: Continuum.

Hayward, K. (2000). Experimental Phonetics. Great Britain: Pearson Education

Ishafit, J. (1998). Analisis Pengukuran Fisika. Yogyakarta: Universitas Ahmad Dahlan.

Larry, D.G., \& Farmington. (2015). Fishing Lure with Mechanically Actuated Lower Frequency Tone Generation Device. United States Patent Goosey

Leman, D. \& Lubis, C.P. (2021). Pemanfaatan video pembelajaran dengan aplikasi Camtasia dan audacity. J-Pemas STMIK Amik Riau. 2(2). 20-27. Retrieved

from:

http://jurnal.sar.ac.id/index.php/JPEMAS/article/view/740

Macig, A., Wauer, J. (2005). Solution of the twodimensional wave equation by using wave polynomials. J Eng Math 51, 339-350. https://doi.org/10.1007/s10665-004-4282-8

Muhafid, E.A., \& Primadi, M.R. (2014). Pengembangan Alat Eksperimen Bunyi Dengan Sistem Akuisisi Data Berbasis Smartphone Android. Jurnal Fisika 4(2). https://doi.org/10.15294/jf.v4i2.3831

Novikarany, R. (2010). Sistem Pengukuran Kecepatan Gelombang Bunyi di Udara berbasis mikrokontroller. Skripsi. Program studi Fisika Instrumentasi Universitas Indonesia.
Nursulistiyo. (2015). Pemanfaatan Suling Bambu Pentatonik Sebagai Media Pembelajaran Fisika. Conference: Seminar Nasional Quantum 2015 At: Universitas Ahmad Dahlan. Retrieved from: https://www.researchgate.net/pxcublication $\angle 283572025$

Pandeya, Y.R., Kim, D., \& Lee, J. (2018). Domestic Cat Sound Classification Using Learned Features from Deep Neural Nets. Applied Sciences. 8(10):1949. https://doi.org/10.3390/app8101949

Pranoto, M.S. (2018). Analisis Frekuensi, Durasi Dan Intensitas Suara Laki-Laki Dan Perempuan Jawa Menggunakan Perangkat Lunak Praat. Lingua: Jurnal Bahasa, dan Sastra. 14(2). Retrieved from: https://journal.unnes.ac.id/nju/index.php/lingu a/article/view/15237

Tipler, P. A. (1991). Fisika Untuk Sains dan Teknik. Jakarta: Erlangga.

Widayanti, L., \& Pramudya, Y. (2014). Karakteristasi Frekuensi Bonang Barung dengan Menggunakan Audacity. Prosiding Pertemuan Ilmiah XXVIII. Program Studi Magister Pendidikan Fisika Universitas Ahmad Dahlan

Yanto, I.W.R., Wahyoo, U., \& Ali, M. (2015). Pengembangan Media Pembelajaran Menggunakan Seruling Sederhana Berbantuan Softwere Audacity pada Materi Pipa Organa. Jurnal Pendidikan Fisika Tadulako Online (JPFT). 7 (3). Retrieved from: http://jurnal.untad.ac.id/jurnal/index.php/EPFT Larticle/view/14585 